\title{
Renewable and nuclear heresies
}

Jesse H. Ausubel

Program for the Human Environment, The Rockefeller University, 1230 York Avenue, New York, NY 10021, USA

E-mail: ausubel@rockefeller.edu

\begin{abstract}
Renewables are not green. To reach the scale at which they would contribute importantly to meeting global energy demand, renewable sources of energy, such as wind, water and biomass, cause serious environmental harm. Measuring renewables in watts per square metre that each source could produce smashes these environmental idols. Nuclear energy is green. However, in order to grow, the nuclear industry must extend out of its niche in baseload electric power generation, form alliances with the methane industry to introduce more hydrogen into energy markets, and start making hydrogen itself. Technologies succeed when economies of scale form part of their conditions of evolution. Like computers, to grow larger, the energy system must now shrink in size and cost. Considered in watts per square metre, nuclear has astronomical advantages over its competitors.
\end{abstract}

Keywords: decarbonisation; electricity; environmental impact; nuclear power; renewable energy.

Reference to this paper should be made as follows: Ausubel, J.H. (2007) 'Renewable and nuclear heresies', Int. J. Nuclear Governance, Economy and Ecology, Vol. 1, No. 3, pp.229-243.

Biographical notes: Jesse Ausubel spent the first decade of his career in Washington DC working with the National Academy of Sciences and National Academy of Engineering. On behalf of the academies, he was one of the main organisers of the first UN World Climate Conference in Geneva in 1979. He was also the main author of the 1983 report Changing Climate, the first comprehensive review of the greenhouse effect. In 1989 he moved to Rockefeller to establish a research programme on the long-term interactions of technology and the environment, patterns of technological diffusion, and means for a large, prosperous society that spares nature.

\section{Introduction}

Heretics maintain opinions at variance with those generally received. Putting heretics to death, hereticide, is common through history. In 1531 the Swiss Protestant heretic Huldreich Zwingli soldiering anonymously in battle against the Catholic cantons was speared in the thigh and then clubbed on the head. Mortally wounded, he was offered the services of a priest. His declination caused him to be recognised, whereupon he was killed and quartered, and his body parts mixed with dung and ceremonially burned. Recall that the first heresy against the Roman Church in Switzerland in 1522 was the eating of sausages during Lent, and the signal heresy was opposition to the baptism of 
children. As nuclear experts know deeply, humans are not rational in their beliefs, actions or reactions.

I will offer both renewable and nuclear heresies. I trust readers will not commit hereticide. Because culture defines heresies, readers coming from a nuclear tribe will probably applaud my renewable heresies and grumble about the nuclear. While my heresies may not rival favouring polygamy or sharing all worldly goods, they will disturb many. My main heresies are that renewable sources of energy are not green and that the nuclear industry should make a product beside electricity.

\section{Decarbonisation}

The dogma that gives me conviction to uphold heresies is decarbonisation, which I accept as the central measure of energy evolution. Consider our hydrocarbon fuels as blends of carbon and hydrogen, both of which burn to release energy. Molecules of the main so-called fossil fuels, coal, oil and natural gas, each have a typical ratio of carbon to hydrogen atoms. Methane, $\mathrm{CH}_{4}$, is obviously 1 to 4 . An oil such as kerosene is 1 to 2 . A typical coal's ratio of $\mathrm{C}: \mathrm{H}$ is about 2 to 1 . Importantly, coal's precursor, wood, has an even more primitive $\mathrm{C}: \mathrm{H}$ ratio, 10 to 1 , once the moisture is removed. Carbon blackens miners' lungs, endangers urban air and threatens climate change. Hydrogen is as innocent as an element can be, ending combustion as water.

Suppose we placed all the hydrocarbon fuels humanity used each year since about 1800, when British colliers first mined thousands of tons of coal, in a blender, mixed them, and plotted the yearly ratio of carbon to hydrogen. While the trend may waver for a decade or two, over the long term $\mathrm{H}$ gains in the mix at the expense of $\mathrm{C}$, like cars replacing horses, colour TV substituting for black-and-white, or email gaining the market over hard copies sent through the post office. The consequent decarbonisation is the single most important fact from 30 years of energy studies.

When my colleagues Cesare Marchetti, Nebojsa Nakicenovic, Arnulf Grubler and I discovered decarbonisation in the 1980 s, we were pleasantly surprised. When we first spoke of decarbonisation, few believed and many ridiculed the word. Everyone 'knew' the opposite to be true. Now prime ministers and presidents speak of decarbonisation. Neither Queen Victoria nor Abraham Lincoln decreed a policy of decarbonisation. Yet, the energy system pursued it. Human societies pursued decarbonisation for 170+ years before anyone noticed. By the way, another of my heresies is the belief that much of the time politicians pull on disconnected levers.

Returning to carbon, if world economic production or all energy rather than all hydrocarbons form the denominator, the world is also decarbonising, that is, using less carbon per dollar of output or kilowatt (Figure 1). Moreover, China and India as well as France and Japan decarbonise. The slopes are quite similar, though China and India lag by several decades, as they do in the diffusion of other technologies besides energy. Economically and technically, carbon seems fated to fade gradually over this century. By 2100 we will feel nostalgia for carbon as some do now for steam locomotives. Londoners have mythologised their great fogs, induced by coal as late as the 1950s, and Berliners already reminisce about the 'East Smell' of burnt lignite whose use collapsed after the fall of The Wall in 1989. 
Figure 1 Decarbonisation as falling global carbon intensity of total world primary energy

Falling Global Carbon Intensity of Primary Energy

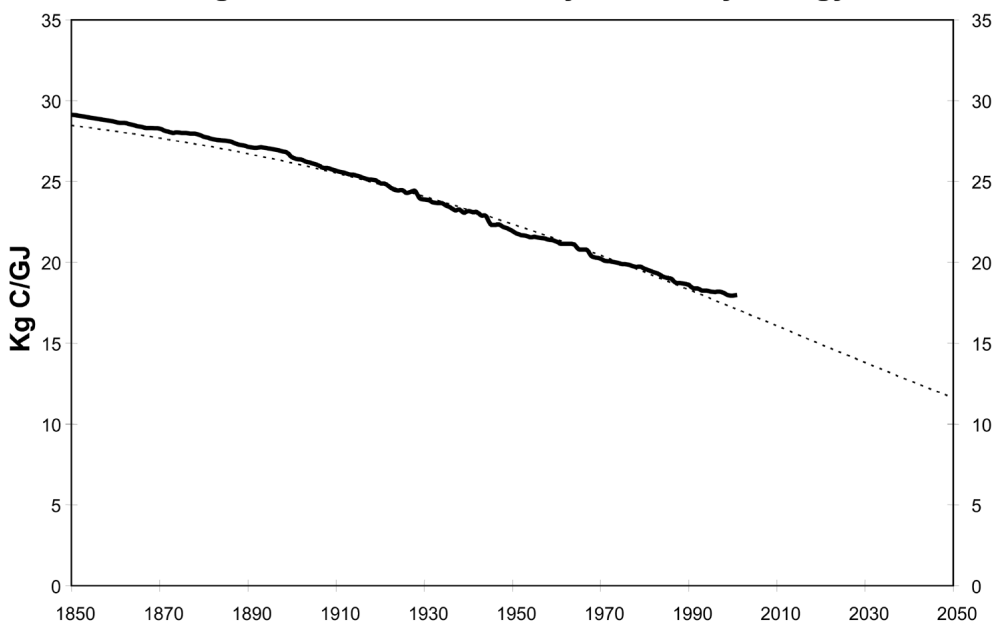

Data sources: IIASA, BP (1965-2001), CDIAC,

http://cdiac.esd.ornl.gov/trends/emis/em_cont.htm

Source: $\quad$ N.M. Victor and J.H. Ausubel

The explanation for the persistence of decarbonisation is simple and profound. The overall evolution of the energy system is driven by the increasing spatial density of energy consumption at the level of the end user, that is, the energy consumed per square metre, for example, in a city. Finally, fuels must conform to what the end user will accept, and constraints become more stringent as spatial density of consumption rises. Rich, dense cities accept happily only electricity and gases, now methane and later hydrogen. These fuels reach consumers easily through pervasive infrastructure grids, right to the burner tip in your kitchen.

My city, New York, by the way, already consumes in electricity alone on a July day about 15 watts per square metre averaged over its entire 820 square kilometres of land, including Central Park.

A few decades ago, some visionaries dreamed of an all-electric society. Today people convert about $35-40 \%$ of all primary fuel to electricity. The fraction will rise, but now even electricity enthusiasts (as I am) accept that finally not much more than half of all energy is likely to be electrified. Reasons include the impracticality of a generating system geared entirely to the instant consumption of energy and lack of amenability of many vehicles to reliance on electricity. Surrendering the vision of an all-electric society is a minor nuclear heresy.

Ultimately the behaviour of end-users drives the system. Happily, the system can thus be rational even when individuals are not. When end-users want electricity and hydrogen, over time the primary energy sources that can produce on the needed scale while meeting the ever more stringent constraints that attend growth in turn will win. Economies of scale are a juggernaut over the long run. Think, for better or worse, of Walmart stores.

Appropriately, the historical growth of world primary energy consumption over the past 150 years shows rises in long waves of 50-60 years, each time formed around 
the development of a more desirable source of energy that scaled up readily. Coal lifted the first wave, and oil the second. A new growth wave is underway, lifted by methane, now almost everyone's favourite fuel and a subject to which I will return later.

According to the historical trend in decarbonisation, large-scale production of carbon-free hydrogen should begin about the year 2020. So how will humanity keep lifting electricity production while also introducing more $\mathrm{H}_{2}$ into the system to lift the average above the norm of methane? The obvious competitors are nuclear and the so-called renewables, the false and minor, yet popular, idols.

\section{Renewable heresies}

Let's consider the renewable idols: hydro, biomass, wind and solar. As a Green, I care intensely about land-sparing, about leaving land for Nature. In fact, a Green credo is 'No new structures'. Or, in milder form, 'New structures or infrastructures should fit within the footprint of the old structures or infrastructures'. So, I will examine renewables primarily by their use of land.

In the USA and much of the rest of the world, including Canada, renewables mean dammed rivers. Almost $80 \%$ of so-called US renewable energy is hydro, and hydro generates about $60 \%$ of all Canada's electricity.

For the USA as a whole, the capacity of all existing hydropower plants is about $97,500 \mathrm{MWe}$, and their average production is about 37,500 MWe. The average power intensity - the watts divided by the land area of the USA - is 0.005 watts per square metre, that is, the approximate power that can be obtained from a huge tract of land that drains into a reservoir for a power station.

Imagine the entire province of Ontario, about 900,000 square $\mathrm{km}$, collecting its entire 680,000 billion litres of rain, an average annual rainfall of about $0.8 \mathrm{~m}$. Imagine collecting all that water, every drop, behind a dam of about 60 metres height. Doing so might inundate half the province, and thus win the support of the majority of Canadians, who resent the force of Ontario. This comprehensive 'Ontario Hydro' would produce about $11,000 \mathrm{MW}$ or about four fifths the output of Canada's 25 nuclear power stations, or about 0.012 watts per square metre or more than twice the USA average. In my 'flood Ontario' scenario, a square kilometre would provide the electricity for about 12 Canadians.

This low density and the attending ecological and cultural headaches explain the trend in most of the world from dam building to dam removal. About $40 \%$ of Canada's immense total land area is effectively dammed for electrons already. The World Commission on Dams issued a report in November 2000 that essentially signalled the end of hydropower development globally. While the Chinese are constructing more dams, few foresee even ten thousand megawatts' further growth from hydropower.

Though electricity and hydrogen from hydro would decarbonise, the idol of hydro is itself dammed. Hydro is not green.

In the USA, after hydro's $80 \%$ comes biomass's $17 \%$ of renewables. Surprisingly, most of this biomass comes, not from backyard woodsmen or community paper drives, but from liquors in pulp mills burned to economise their own heat and power. In terms of decarbonisation, biomass of course retrogresses, with $10 \mathrm{Cs}$ or more per $\mathrm{H}$.

If one argues that biomass is carbon-neutral because photosynthesis in plants recycles the carbon, one must consider its other attributes, beginning with productivity of 
photosynthesis. Although farmers usually express this productivity in tons per hectare, in the energy industry the heat content of the trees, corn and hay instead quantify the energy productivity of the land. For example, the abundant and untended New England or New Brunswick forests produce firewood at the renewable rate of about 1200 watts (thermal) per hectare averaged around the year. The 0.12 watts per square metre of biomass is about ten times more powerful than rain, and excellent management can multiply the figure again ten times.

Imagine, as energy analyst Howard Hayden has suggested, farmers use ample water, fertiliser, and pesticides to achieve 12,000 watts thermal per hectare $(10,000$ square metres). Imagine replacing a 1000 MWe nuclear power plant with a $90 \%$ capacity factor. During a year, the nuclear plant will produce about 7.9 billion $\mathrm{kWh}$. To obtain the same electricity from a power plant that burns biomass at $30 \%$ heat-to-electricity efficiency, farmers would need about 250,000 hectares or 2500 square kilometres of land with very high productivity. Harvesting and collecting the biomass are not $100 \%$ efficient; some gets left in fields or otherwise lost.

Such losses mean that in round numbers a 1000 MWe nuclear plant equates to more than 2500 square kilometres of prime land. A typical Iowa county spans about 1000 square kilometres, so it would take at least two and a half counties to fire a station. A nuclear power plant consumes about ten hectares per unit or 40 hectares for a power park. Shifting entirely from baconburgers to kilowatts, Iowa's 55,000 square miles might yield 50,000 MWe. Prince Edward Island might produce about $2000 \mathrm{MWe}$.

The USA already consumes about ten and the world about 40 times the kilowatt hours that Iowa's biomass could generate. Prime land has better uses, like feeding the hungry. Ploughing marginal lands would require ten or 20 times the expanse and increase erosion. One hundred twenty square metres of New Brunswick or Manitoba might electrify one square metre of New York City.

Note also that pumping water and making fertiliser and pesticides also consume energy. If processors concentrate the corn or other biomass into alcohol or diesel, another step erodes efficiency. Ethanol production yields a tiny net of 0.05 watts per square metre.

As in hydro, in biomass the lack of economies of scale loom large. Because more biomass quickly hits the ceiling of watts per square metre, it can become more extensive but not cheaper. If not false, the idol of biomass is not sustainable on the scale needed and will not contribute to decarbonisation. Biomass may photosynthesise but it is not green.

Although, or because, wind provides only $0.2 \%$ of US electricity, the idol of wind evokes much worship. The basic fact of wind is that it provides about 1.2 watts per square metre or 12,000 watts per hectare of year-round average electric power. Consider, for example, the \$212 million wind farm about 30 kilometres south of Lamar, CO, where $1081.5 \mathrm{MWe}$ wind turbines stand 80 metres tall, their blades sweeping to 115 metres. The wind farm spreads over 4800 hectares. At $30 \%$ capacity, peak power density is the typical 1.2 watts per square metre.

One problem is that two of the four wind speed regimes produce no power at all. Calm air means no power of course, and gales faster than 25 metres per second (about 90 kilometres per hour) mean shutting down lest the turbine blow apart. Perhaps three to ten times more compact than biomass, a wind farm occupying about 770 square kilometres could produce as much energy as one 1000 MWe nuclear plant. To meet 2005 US electricity demand of about four million MWhr with around-the-clock-wind would have required wind farms covering over 780,000 square kilometres, about Texas plus 
Louisiana, or about 1.2 times the area of Alberta. Canada's demand is about $10 \%$ of the USA and corresponds to about the area of New Brunswick.

For linear thinkers, a single file line of windmills has a power density of about 5 kilowatts per metre. If Christo could string windmills single file along Rocky Mountain ridges half way from Vancouver to Calgary, about $1200 \mathrm{~km}$, the output would be about the same as one of the four Darlington CANDU units.

Rapidly exhausted economies of scale stop wind. One hundred windy square metres, a good size for a Manhattan apartment, can power a lamp or two, but not the clothes washer and dryer, microwave oven, plasma TVs or computers or dozens of other devices in the apartment, or the apartments above or below it. New York City would require every square metre of Connecticut to become a windfarm if the wind blew in Hartford as in Lamar. The idol of wind would decarbonise but will be minor.

Although negligible as a source of electric power today, photovoltaics also earn a traditional bow. Sadly, PVs remain stuck at about $10 \%$ efficiency, with no breakthroughs in 30 years. Today performance reaches about 5-6 watts per square metre. But no economies of scale inhere in PV systems. A $1000 \mathrm{MWe}$ PV plant would require about 150 square kilometres plus land for storage and retrieval. Present USA electric consumption would require 150,000 square kilometres or a square almost 400 kilometres on each side. The PV industry now makes about 600 metres by 600 metres per year. About 600,000 times this amount would be needed to replace the 1000 MWe nuclear plant, but only a few square kilometres have ever been manufactured in total.

Viewed another way, to produce with solar cells the amount of energy generated in one litre of the core of a nuclear reactor requires one hectare of solar cells. To compete at making the millions of megawatts for the baseload of the world energy market, the cost and complication of solar collectors still need to shrink by orders of magnitude while efficiency soars.

Extrapolating the progress (or lack) in recent decades does not carry the solar and renewable system to market victory. Electrical batteries, crucial to many applications, weigh almost zero in the global energy market. Similarly, solar and renewable energy may attain marvellous niches, but seem puny for providing the base power for 8-10 billion people later this century.

While I have denominated power with land so far, solar and renewables, despite their sacrosanct status, cost the environment in other ways as well. The appropriate description for PVs comes from the song of the Rolling Stones, 'Paint It Black'. Painting large areas with efficient, thus black, absorbers evokes dark 19th century visions of the land. I prefer colourful desert to a $150,000 \mathrm{~km}^{2}$ area painted black. Some of the efficient PVs contain nasty elements, such as cadmium. Wind farms irritate with low-frequency noise and thumps, blight landscapes, interfere with TV reception, and chop birds and bats. At the Altamont windfarm in California, the mills kill 40-60 golden eagles per year. Dams kill rivers.

Moreover, solar and renewables in every form require large and complex machinery to produce many megawatts. Berkeley engineer Per Petersen reports that for an average MWe a typical wind-energy system operating with a 6.5 metres-per-second average wind speed requires construction inputs of 460 metric tons of steel and 870 cubic metres of concrete. For comparison, the construction of existing 1970-vintage US nuclear power plants required 40 metric tons of steel and 190 cubic metres of concrete per average megawatt of electricity generating capacity. Wind's infrastructure takes five to ten times the steel and concrete as that of nuclear. Bridging the cloudy and dark as well as calm and 
gusty weather takes storage batteries and their heavy metals. Without vastly improved storage, the windmills and PVs are supernumeraries for the coal, methane and uranium plants that operate reliably round the clock day after day.

Since 1980 the US DOE alone has spent about $\$ 6$ billion on solar, \$2 billion on geothermal, $\$ 1$ billion on wind and $\$ 3$ billion on other renewables. The nonhydro renewable energy remains about $2 \%$ of US capacity, much of that the wood byproducts used to fuel the wood products industry. Cheerful self-delusion about new solar and renewables since 1970 has yet to produce a single quad of the more than 90 quadrillion Btu of the total energy the US now yearly consumes. In the 21 years from 1979 to 2000 the percentage of US energy from renewables actually fell from 8.5 to $7.3 \%$. Environmentally harmless increments of solar and renewable megawatts look puny in a 20 or 30 million megawatt world, and even in today's 10 million megawatt world. If we want to scale up, then hydro, biomass, wind, and solar all gobble land from Nature. Let's stop sanctifying false and minor gods and heretically chant 'Renewables are not Green'.

\section{Nuclear heresies}

How then can we meet more stringent consumer demands and stay on course for decarbonisation? The inevitable reply is nuclear energy. I should mention that I am not naïve about nuclear. Privileged to work with Soviet colleagues who participated in the Chernobyl clean-up, I saw the Dead Zone in 1990 with my own eyes. I visited the concrete sarcophagus encasing the blasted reactor with employees of the site management enterprise. But I will not offer heresies here about safety, waste disposal and proliferation, though important heresies exist, particularly about waste disposal.

Rather, my first nuclear heresy is that nuclear must ally with methane. Electric utilities that operate nuclear plants often embrace another source of power, for example, coal or hydro. Yet, importantly, the sheltering wing of methane will help nuclear grow again. The biggest fact of the energy system over the next 20 to 30 years will continue to be a massive expansion of the gas system, methane for the present, and many people may feel more comfortable with the addition of nuclear power plants if they know that methane, an attractive fuel in many ways, is taking the overall energy lead. To stay on track in decarbonisation, methane must and will prevail. Were I a businessman, I would want to ally with a winner, and methane will prosper in the market.

Here I will offer a pair of heresies. One is that the popular spectre of resource exhaustion has played little or no role in the long-run evolution of the energy system. Plenty of wood and hay remained to be exploited when the world shifted to coal. Coal abounded when oil rose. Oil abounds now as methane rises. Advocates of nuclear energy and so-called renewables foolishly point to depletion of oil and natural gas as reasons for their own fuels to win. Oil and natural gas use may peak in coming decades but not because Earth is running out of them.

Not only do I reject the doctrine of resource exhaustion, I also reject the very notion of fossil fuels. The prevailing theory among Western scientists is that petroleum derives from the buried and chemically transformed remains of once-living cells. This theory relies on the long unquestioned belief that life can exist only at the surface of Earth. In fact, as the late Thomas Gold of Cornell University showed, a huge, deep, hot biosphere of microbes flourishes within Earth's crust, down to the deepest levels we drill. 
Consider instead an upwelling theory. Primordial, abiogenic carbon which we know abounds on other planetary bodies enters the crust from below as a carbon-bearing fluid such as methane, butane or propane. Continual loss of hydrogen brings it closer to what we call petroleum or coal. Oil is very desirable to microbes, and the deep hot biosphere adds bioproducts to the hydrocarbons. These have caused us to uphold the false belief that the so-called fossil fuels are the stored energy of the Sun. They are not the stored energy of the Sun but primordial hydrocarbons from deep in Earth. And they keep refilling oil and gas reservoirs from below. The alternate theory of the origins of gas, oil and coal will revolutionise Earth sciences over the next two or three decades, lift estimates of resource abundance, and reveal resources in unexpected places.

By the way, rejection of the fossil dogma offers an alternate explanation as to why by far the greatest human contribution to radioactive pollution is not leakage from the wastes and cooling water of nuclear power plants but uranium-rich plumes from the smokestacks of coal-fired power stations. Terrestrial plants do not concentrate uranium, but an underground charcoal filter for upwelling gases carrying trace elements would.

Anyway, for business to continue as usual, by 2020 the reference point for the world's energy will be $\mathrm{CH}_{4}$, methane. Still, energy's evolution should not end with methane. The completion of decarbonisation ultimately depends on the production and use of pure hydrogen. In the 1970s journalists called hydrogen the Tomorrow Fuel, and critics have worried that hydrogen will remain forever on the horizon, like fusion. For hydrogen tomorrow is now today. Hydrogen is a thriving young industry. World commercial production in 2002 exceeded 40 billion standard cubic feet per day, equal to 75,000 MW if converted to electricity, and USA production, which is about a third of the world's, multiplied tenfold between 1970 and 2003 (Figure 2). Over 16,000 kilometres of pipeline transport $\mathrm{H}_{2}$ gas for big users, with pipes at 100 atmospheres as long as 400 kilometres from Antwerp to Normandy. High pressure containers such as tube trailers distribute the liquid product to small and moderate users throughout the world. With production experience, the hydrogen price is falling (Figure 3).

Figure 2 USA hydrogen shipments growth to 2003

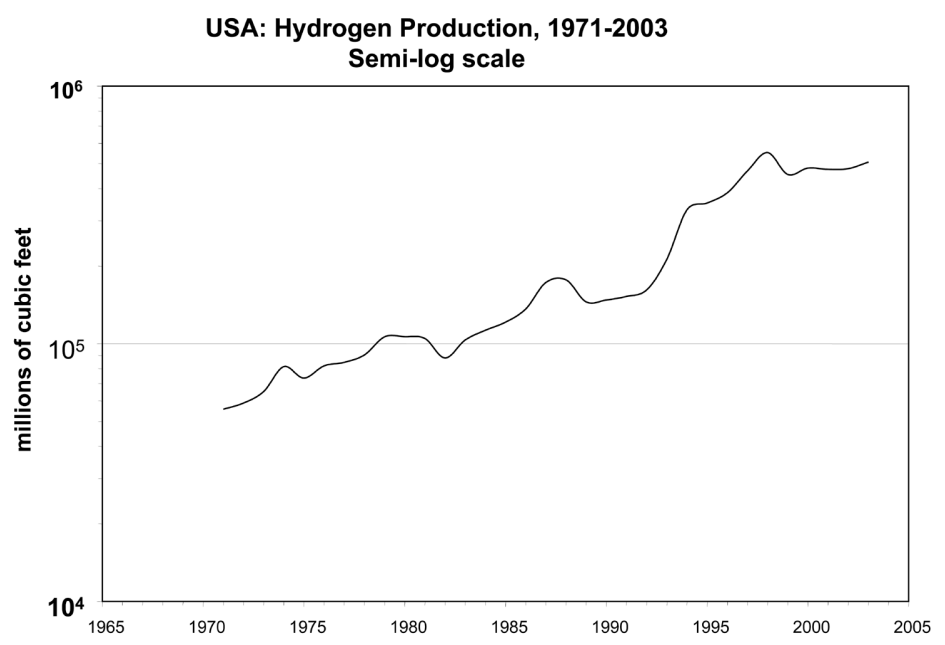

Data source: Dale Simbeck/SFA Pacifics 
Figure 3 Falling hydrogen price with production (learning curve)

Falling hydrogen price versus hydrogen production, USA, 1971-2003

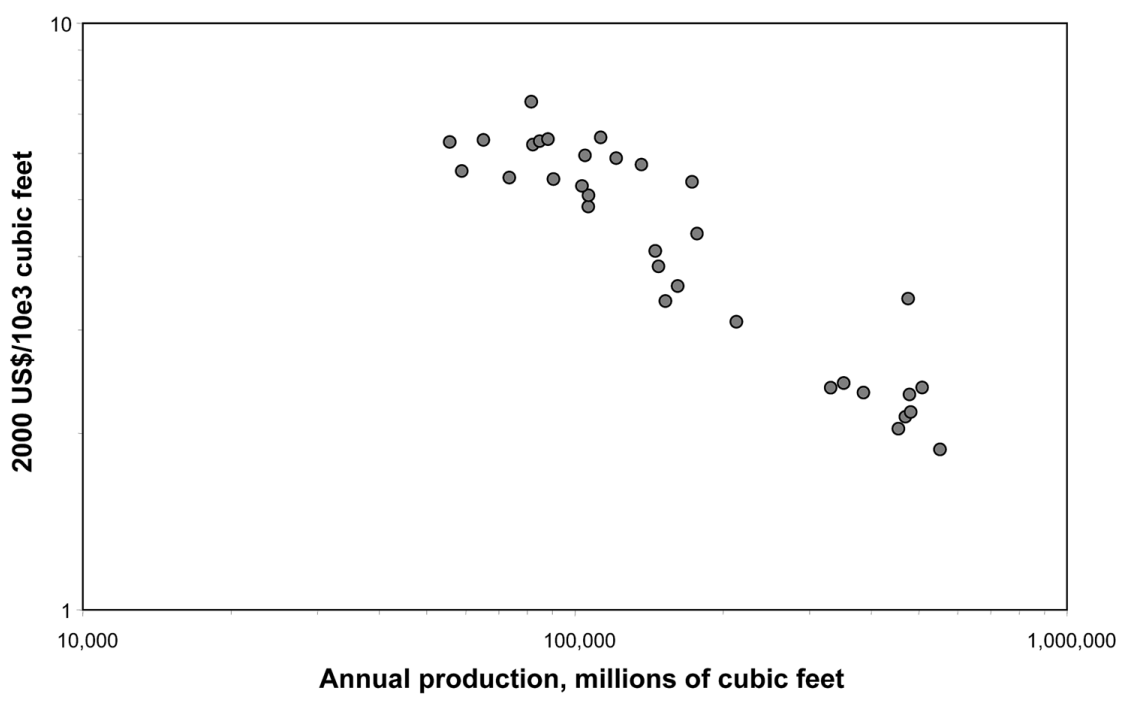

Source: N.M. Victor and J.H. Ausubel

The fundamental question then becomes, from where will large quantities of cheap hydrogen come? Methane and water will compete to provide the hydrogen feedstock, while methane and nuclear will compete to provide the energy needed to transform the feedstock.

Steam reforming of methane to produce hydrogen is already a venerable chemical process. Because methane abounds, in the near term steam reforming of methane, using heat from methane, will remain the preferred way to produce hydrogen. Moreover, because much of the demand for hydrogen is within the petrochemical industry, nepotism gives methane an edge. Increasingly, as new applications such as fuel cells demand hydrogen, nuclear's chance to compete as the transformer improves.

My next heresy is that the production of hydrogen will revolutionise the economics of nuclear power much more than standardising plants or building plants quicker. Firstly, hydrogen manufacture allows nuclear plants to address the half of energy demand that will not be met by electricity. Secondly, it gives nuclear power plants the chance to make valuable product 24 hours per day. Recall that a great problem the electric power industry faces is that, notwithstanding the talk of the '24/7 society', electric power demand remains asymmetrical. Users demand most electricity during the day. So, immense capital sits on its hands between about 9 O'clock at night and 6 or 7 O'clock in the morning. Turning that capital into an asset is incredibly valuable. Like the hotel and airline industries, the power industry would rather operate at $90 \%$ capacity than $60 \%$ capacity. The nuclear industry is limited to providing baseload electric power unless it reaches out to hydrogen to store and distribute its tireless energy.

While I stated earlier that methane and nuclear compete, they can also cooperate in the hydrogen market. Let's accept that in the near term steam reforming of methane will dominate hydrogen making. Nuclear power as well as methane can provide the energy for 
the reforming. Here let me share a big technological idea, methane-nuclear-hydrogen (MNH) complexes, first sketched by Cesare Marchetti. An enormous amount of methane travels through a few giant pipeline clusters, for example, from Russia through Ukraine and Slovakia. These methane trunk routes are attractive places to assemble $\mathrm{MNH}$ industrial complexes. Here, if one builds a few nuclear power plants and siphons off some of the methane, the nuclear plants could profitably manufacture large amounts of hydrogen that could be re-introduced into the pipelines, say up to $20 \%$ of the composition of the gas. This decarbonisation enhances the value of the gas. Meanwhile, the carbon separated from the methane becomes $\mathrm{CO}_{2}$ to be injected into depleted oil and gas fields and profitably help with tertiary recovery. The hydrogen mixture could be distributed around Europe, or the world, getting users accustomed to the new level of decarbonisation.

Over the next 10-15 years, I will keep my eye on the places where much gas flows and see whether these regions initiate this next generation energy system. Alberta is an obvious locale, especially when methane from the Mackenzie Delta flows through it. The experience of working with hydrogen from methane will benefit the nuclear industry as it put nuclear plants at the nodes of the webs of hydrogen distribution, anticipating the shift from $\mathrm{CH}_{4}$ to $\mathrm{H}_{2} \mathrm{O}$ as a feedstock. The methane-nuclear-hydrogen complexes can be the nurseries for the next generation of the energy system.

The surprising longevity of nuclear power plants, observed by Alvin Weinberg, spurs me to look beyond the imminent methane era to complete decarbonisation. Nuclear energy's long-range potential is unique as an abundant, scalable source of electricity and for water-splitting while the cities sleep.

It may no longer qualify as a heresy but I am convinced the thermochemical processes have more promise than electrolysis for producing hydrogen because of the large plant areas required for electrolysis, especially if the electrolytic plants have very low power density, like photovoltaics. The power density of the machinery and thus the space required for a plant makes the use of electrolysis for the large-scale production of hydrogen problematic. Economies of scale determine fate again.

At about $950^{\circ} \mathrm{C}$ core outlet temperature, a high-temperature reactor could successfully drive, for example, a sulphur-iodine thermochemical process. High-temperature reactors with coated-particle or graphite-matrix fuels promise a particularly high-efficiency and scalable route to combined power and hydrogen production. A consortium of Chinese companies led by Huaneng proposes to have the first commercially operated pebble bed reactor producing electricity within five years. Thermochemically, such nuclear plants could nightly make $\mathrm{H}_{2}$ on the scale needed to meet the demand of billions of consumers. In Canada questioning CANDU reactors is heresy, but I wonder whether they can reach temperatures good for hydrogen production. With appropriate reactors, hydrogen production can draw the nuclear industry to a scale of operation an order of magnitude larger than today, meeting future demand for hydrogen and electricity in immense dense cities.

Here let me introduce a big technological concept, the continental SuperGrid to deliver electricity and hydrogen in an integrated energy pipeline. Championed by Chauncey Starr of EPRI, the Supergrid is doubly super: firstly because it is the apex, and secondly because it employs superconductivity. Specifically, the SuperGrid would use a high-capacity, superconducting power transmission cable cooled with liquid hydrogen produced by advanced nuclear plants. The fundamental design is for liquid hydrogen to be pumped through the centre of an evacuated energy pipe (Figure 4). Thus, the SuperGrid would 
not only transmit electricity but also store and distribute the bulk of the hydrogen ultimately used in fuel-cell vehicles and generators or refreshed internal combustion engines.

Figure 4 Supergrid energy pipe for electricity and hydrogen

\section{Supergrid Energy Pipeline}

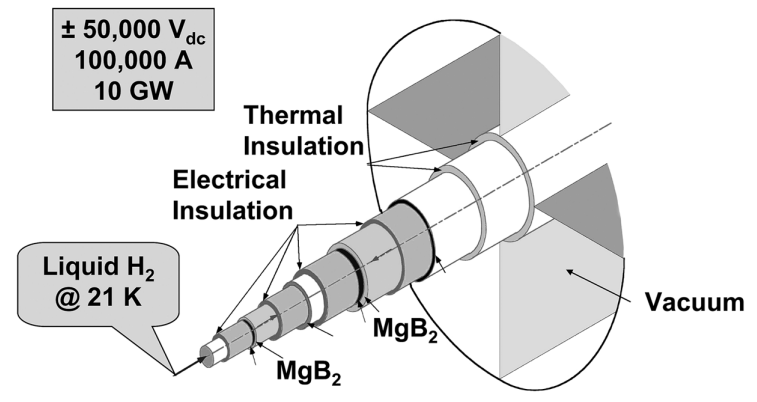

Source: http://www.epri.com/journal/details.asp?id=511\&doctype=features

By continental, I mean coast-to-coast, indeed all of North America, making one market for electricity. SuperGrids should thrive on other continents, of course, but as an American I hope North America builds first and dominates the market for these systems, which in rough terms might cost $\$ 1$ trillion, or $\$ 10$ billion per year for 100 years. The continental scale makes the electric power system much more efficient by flattening the electricity load curve, which still follows the sun. Superconductivity solves the problem of power-line losses. High capacity means 40,000-80,000 MW. The latent hydrogen storage capacity of the SuperGrid, combined with fuel cells, may allow electricity networks to shift to a delivery system more like oil and gas, away from the present, costly, instant matching of supply to demand.

Technical choices and challenges abound, about cryogenics and vacuums, about dielectric materials under simultaneous stress from low temperature and high fields, about power control and cable design. Engineers need to improve supercable design and demonstrate performance of high temperature superconducting wire at commercial electrical current levels. The next step, achievable over two to three years, might be a flexible 100 metre supercable, 10 centimetres overall diameter, 5000 volts, 2000 amperes, $10 \mathrm{MW}$ direct current, with a 3-centimetre diameter pipe for 1 metre per second $\mathrm{H}_{2}$ flow, using magnesium diboride or other wire demonstrating constant current under variable load and low ripple factor. Looking forward, joints and splices are tough problems, emblematic of the general problem of making parts into a system that works, a problem that challenges engineers to their greatest achievements.

For ultimate safety, security, and aesthetics, let's put the SuperGrid, including its cables and power plants, underground. The decision to build underground critically determines the cost of the SuperGrid. But, benefits include reduced vulnerability to attack by chance or sabotage, fewer right-of-way disputes, reduced surface congestion, and real and perceived reduced exposure to accidents and fallout. US Department of Energy laboratories, including Fermi, have profound experience with tunnelling from 
building particle colliders. Since 1958 Russia has operated underground nuclear reactors near Zheleznogorsk in Central Siberia. Wes Myers and Ned Elkins of Los Alamos National Lab have suggested that the region near Carlsbad, New Mexico, which has enormous caverns from potash mining, and thus a rail and highway system, water supply network and electrical power distribution, might be well-suited for the first USA underground nuclear park. The SuperGrid multiplies the chances to site reactors that produce hydrogen far from population concentrations and pipe their products to consumers. One could imagine a region like Idaho, where the USA may build its first high temperature reactor, becoming the Kuwait of hydrogen.

Magic words for the SuperGrid are hydrogen, superconductivity, zero emissions and small ecological footprint, to which we add high-temperature reactors, energy storage, security, reliability and scalability. The long road to the continental SuperGrid begins with the first 10 to $20 \mathrm{~km}$ segment addressing an actual transmission bottleneck.

By now, I have revealed my final heresy, that nuclear is green. An American now yearly emits about five tons of carbon per year or $14 \mathrm{~kg}$ per day. Globally each year humanity already produces carbon waste measuring about 15 cubic kilometres, a very large refuse bag. The volume of nuclear wastes is usually measured in litres. By weight, a $1000 \mathrm{MWe}$ light water reactor that produces energy for one million typical homes produces approximately $1080 \mathrm{~kg}$ of fission products per year, 4 milligrams per person. A large apartment building housing 500 people would produce annually high-level radioactive waste equal to a small jar of aspirin tablets.

Over 500 years, in a fully nuclear world the high level radioactive wastes might amount to 700 million tonnes, less than the 800 million tons of coal Americans burn in one year to produce half of USA electricity. Hayden calculates that all the reactors from 500 years of production of $100 \%$ of the world's energy could be stacked one high in an area of a little over 250 square kilometres, about the land area for a solar farm to provide $1000 \mathrm{MW}$ of power. I recur to scale. Compact enough to grow, nuclear is green.

\section{Conclusion}

Let's return to the heart of energy evolution, decarbonisation. Because hydrogen is much better stuff for burning than carbon, the hydrocarbons form a clear hierarchy (Figure 5). Methane tops the ranking, with an energy density of about 55 megajoules per kilo, about twice that of black coal and three times that of wood.

The energy density of nuclear fuel is 10,000 or even 100,000 times as great as methane (Figure 6). While the full footprint of uranium mining might add a few hundred square kilometres, the dense heart of the atom still has much to offer. The extraordinary energy density of nuclear fuel allows compact systems of immense scale, and finally suits the ever higher spatial density of energy consumption at the level of the end user, logically matching energy consumption and production.

During the past 100 years motors have grown from 10 kilowatts to more than 1000 megawatts, scaling up an astonishing 100,000 times, while shrinking sharply in size and cost per kilowatt. A mere $1.5 \%$ per year growth of total energy demand during the $21 \mathrm{st}$ century, about two-thirds the rate since 1800 , will multiply demand for primary energy to make the electricity and hydrogen from the 13 million MW years in 2002 to 50 million in 2100. If size and power, of individual machines or the total system, grow in tandem, 
use of materials and land and other resources becomes unacceptably costly. Technologies succeed when economies of scale form part of their conditions of evolution. Like computers, to grow larger, the energy system must now shrink in size and cost. Considered in watts per square metre, nuclear has astronomical advantages over its competitors.

Figure 5 Energy density ranking of hydrocarbon fuels

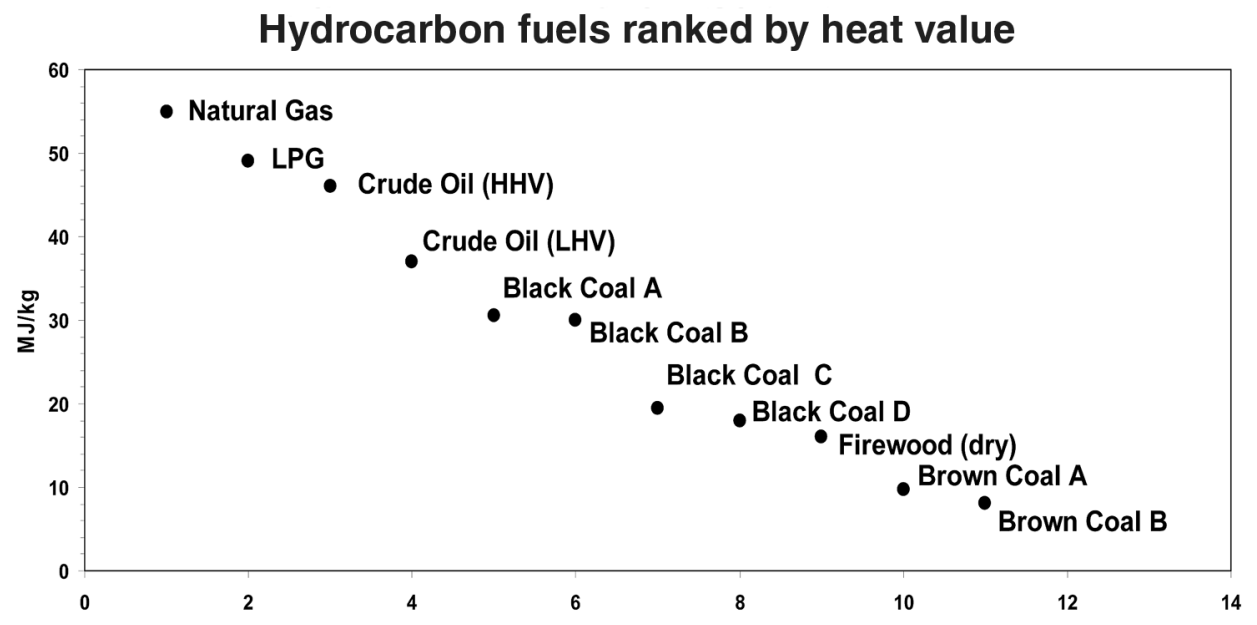

Source: N.M. Victor and J.H. Ausubel

Figure 6 Energy density of nuclear and hydrocarbon fuels

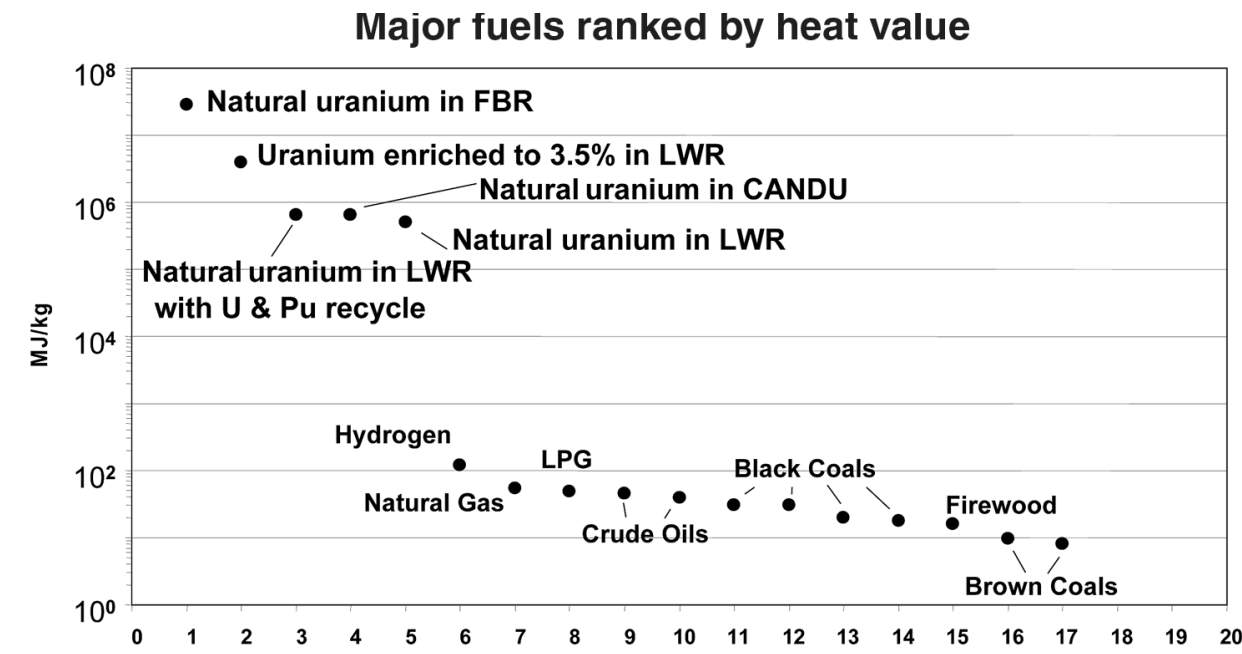

Source: N.M. Victor and J.H. Ausubel

You might well wonder whether we need DO anything. Decarbonisation appears automatic. At one level this is true. Yet, we also know that the trend of decarbonisation is the outcome of all the blood, sweat and tears of persistent workers, engineers, managers, investors, regulators and consumers. If people stop bleeding, sweating, and crying, the game producing decarbonisation could just stop. Without heretics, there are no schisms. 
And energy offers ample room for heresies. I have mentioned several, some large like reading the Bible in one's own tongue, and some small like sausages on Lent:

- decarbonisation has proceeded for almost two centuries and without a policy for it

- renewables are not green

- resource exhaustion is irrelevant

- hydrocarbons are not the stored energy of the Sun

- utilities should embrace nuclear together with methane

- nuclear plants must diversify to make hydrogen as well as electricity

- nuclear is green.

I hope readers will not toss offending documents I have written on a public bonfire or, worse yet, quarter and immolate me like the Swiss heretic Zwingli. Rather, keep in mind the meaning of the Greek word from which heresy derives. The word means to take for oneself or choose.

Received, widely held doctrines may be wise and right. But history, including the history of science, is littered with doctrines discarded as delusions. At present, my conviction is that our best energy doctrine is decarbonisation, and let us complete it within one hundred years or sooner. Wishful thinking holds that the way is by returning to a renewable Eden. Resisting wishful thinking requires courage. Even the courageous Zwingli wrote in the margin of his copy of St. Augustine's City of God, 'Ah God, if only Adam had eaten a pear'.

\section{Acknowledgements}

Thanks to Cesare Marchetti, Perrin Meyer, Chauncey Starr, Nadejda Makarova Victor and Paul Waggoner.

\section{References}

Ausubel, J.H. (1991) 'Energy and environment: the light path', Energy Systems and Policy, No. 15, pp.181-188.

Ausubel, J.H. (1992) 'Chernobyl after Perestroika: reflections on a recent visit', Technology in Society, No. 14, pp.187-198.

Ausubel, J.H. (2003) 'Decarbonisation: the next 100 years', Ninth Alvin M. Weinberg Lecture, Oak Ridge National Laboratory, 5 June 2003. Text: http://phe.rockefeller.edu /PDF_FILES/oakridge.pdf. Slides: http://phe.rockefeller.edu/PDF_FILES/oakridgePPT.pdf.

Bryan, R.H. and Dudley, I.T. (1974) 'Estimated quantities of materials contained in a 1000-MW(e) PWR Power Plant, ORNL-TM-4515', prepared for the US Atomic Energy Commission, Oak Ridge National Laboratory, Oak Ridge TN.

Electric Power Research Institute (EPRI) (2003) 'High temperature gas-cooled reactors for the production of hydrogen: an assessment in support of the hydrogen economy' (1007802), EPRI, Palo Alto, CA.

Freidrich, O. (1986) The End of the World: A History, New York: Fromm. 
Gold, T. (1987) Power from the Earth: Deep Earth Gas, Energy for the Future, London: Dent.

Gold, T. (1999) The Deep Hot Biosphere, New York: Copernicus Springer.

Grant, P.M. 'The Energy Supergrid website', available from: http://www.w2agz.com/ PMG\%20SuperGrid\%20Home.htm.

Grant, P.M., Starr, C. and Overbye, T.J. (2006) 'A power grid for the hydrogen economy', Scientific American, Vol. 295, No. 1, pp.76-83.

Hayden, H.C. The Solar Fraud: Why Solar Energy Won't Run the World, Vale Lakes, Pueblo West CO, 2001; see also Hayden's monthly newsletter, The Energy Advocate, POB 7595, Pueblo West CO 81007.

International Atomic Energy Agency, Power Reactor Information System, available from: http://www.iaea.org/programmes/a2/index.html, accessed 20 May 2004.

Marchetti, C. (1985) 'Nuclear plants and nuclear niches', Nuclear Science and Engineering, No. 90, pp.521-526.

Marchetti, C. (1989) 'How to solve the $\mathrm{CO}_{2}$ problem without tears', International Journal of Hydrogen Energy, No. 14, pp.493-506, available from: http://www.cesaremarchetti.org/ archive/scan/MARCHETTI-013.pdf.

Meier, P.J. (2002) 'Life-cycle assessment of electricity generation systems and applications for climate change policy analysis', UWFDM-1181, Fusion Technology Institute, University of Wisconsin, Madison WI.

Mining Chemical Association (MCA), Zheleznogorsk (Krasnoyarsk-26), A Production Association of the Ministry of Atomic Energy of the Russian Federation (MINATOM), available from: http://www.jccem.fsu.edu/Partners/MCA.cfm, accessed 20 May 2004.

Moore, T. (2002) 'Supergrid sparks interest', EPRI Journal, November, available from: http://www.epri.com/journal/details.asp?id=511\&doctype=features accessed 21 May 2004.

Myers, W. and Elkins, N. (2003) 'Concept for an underground nuclear park and National Energy Supply Complex at Carlsbad', New Mexico, LA-14064, Los Alamos National Laboratory, Los Alamos NM, August.

Nakicenovic, N. and Grübler, A. (1989) 'Technological progress, structural change, and efficient energy use: trends worldwide and in Austria: International part', International Institute for Applied Systems Analysis, Laxenburg, Austria.

Nuclear Energy Institute 'Nuclear data', available from: http://www.nei.org/ index.asp? catnum $=1 \&$ catid $=5$, accessed 20 May 2004.

Overbye, T. and Starr, C. (2002) 'Convenors, Report of the National Energy Supergrid Workshop', Palo Alto CA, 6-8 November, available from: http://www.energy.ece.uiuc.edu/ SuperGridReportFinal.pdf, accessed 21 May 2004.

Peterson, P.F. (2003) 'Will the United States need a second geologic repository?', The Bridge, Vol. 33, No. 3, pp.26-32.

Simbeck, D. 'Data on hydrogen markets and infrastructure', SFA Pacific Inc., Mountain View, CA 94041, available from: http://www.sfapacific.com.

Weinberg, A.M. (2004) 'On 'Immortal' nuclear power plants', Technology in Society, Vol. 26, Nos. 2/3, pp.447-453.

World Commission on Dams, available from: http://www.dams.org/report/wcd_overview.htm. 